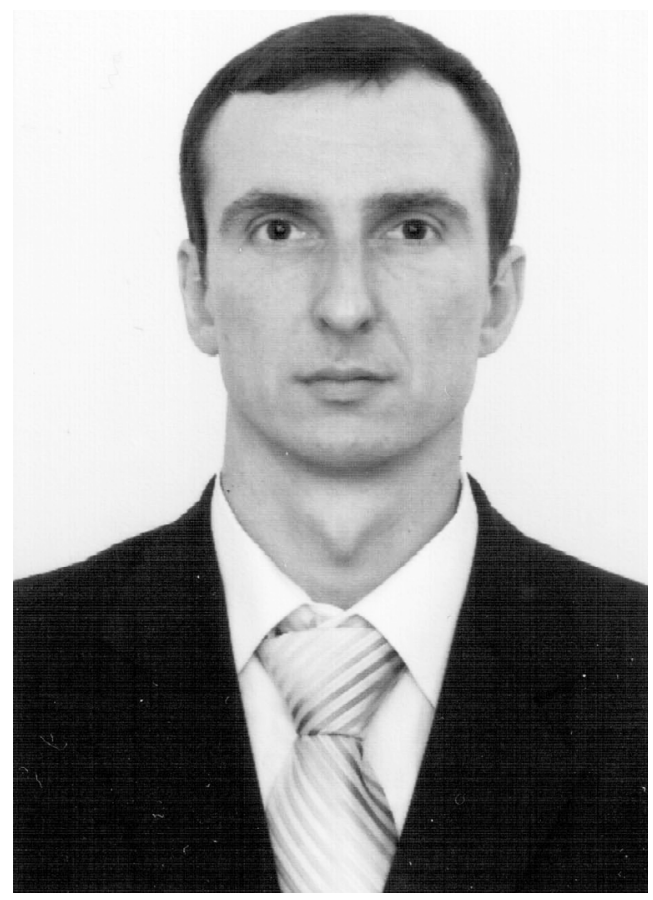

Валюх Андрей Николаевич, директор Учебно-научного института экономики и менеджмента, кандидат экономических наук, доцент, дочент кафедры государственного управления, документоведения и информащионной деятельности, Нащиональньй университет водного хозяйства и природопользования, 33028, г. Ровно, ул. Алексы Новака, 75, тел.: (036) 22300 95, e-mail: a.m.valyukh@ukr.net

ORCID: 0000-0002-0233-1319

DOI https://doi.org/10.31618/vadnd.v1i13.131

\title{
SIGNIFICANCE OF NATURAL CAPITAL MANAGEMENT: ARCHETYPAL APPROACH
}

Abstract. The issues of the essence of the concept of "natural capital", as well as management in the field of conservation of natural capital have been investigated. The author uses an archetypal approach. The activity and structure of international organizations engaged in environmental policy have been analyzed. The basic features aspects and cooperative efforts in biodiversity identified shortcomings for international and suggests ways to address them have been investigated. The basic state policy measures improving conservation and reproduction of natural capital have been ordered.

The basic approaches to evaluating the effectiveness of conservation based on best international experience. The economic evaluation of natural capital resour- 
ces of Ukraine has been done and the necessity of increasing the annual state budgetary financing natural capital conservation has been improved. The methodic of evaluating the effectiveness of conservation on three levels: national, regional and local has been ordered, to better analyze the actual state of natural ecosystems, to investigate the dynamics of the cost of maintaining of natural capital by various sources (state budget of Ukraine, the cost of regional state administrations and local self-government).

The experience of international financing of natural capital conservation through environmental funds has been studied, funds of NGOs and grant projects. Scientific and practical interest in the work is the proposed funding mechanism for biodiversity conservation in the current economic climate of Ukraine. Investigated the organizational structure of government natural capital conservation of Ukraine. The effectiveness of government natural capital's conservation has been investigated. The functions of the Ministry of Ecology and Natural Resources of Ukraine as a central body of executive power in the field of natural capital conservation have been studied and analyzed. The staffing Ministry of Ecology and Natural Resources of Ukraine has been investigated, the system of placement and examined staffing departments of the Ministry, responsible for natural capital Ukraine, has been analyzed. The best foreign practices of natural capital public administration and recommendations for its implementation in Ukraine have been ordered.

Keywords: natural capital, archetypal approach, international cooperation, management.

\section{СУТНІСТЬ УПРАВЛІННЯ ПРИРОДНИМ КАПІТАЛОМ: АРХЕТИПНИЙ ПІДХІД}

Анотація. Розглянуто сутність поняття природний капітал та управління у галузі збереження природного капіталу. Застосовано архетипний підхід у дослідженні. Проаналізовано сутність поняття “природний капітал”. Досліджено основні аспекти та особливості кооперації зусиль у галузі збереження природного капіталу. Запропоновано основні заходи удосконалення державної політики збереження й відтворення природного капіталу.

Розглянуто основні підходи оцінювання ефективності збереження природного капіталу на основі кращого іноземного досвіду. Здійснено економічну оцінку ресурсів природного капіталу України та доведено необхідність збільшення обсягів щорічного держбюджетного фінансування.

Запропоновано методику оцінки ефективності збереження природного капіталу на таких трьох рівнях: загальнодержавному, регіональному та місцевому, що дає можливість краще аналізувати як фактичний стан природних екосистем, досліджувати динаміку витрат на утримання природного капіталу за різними джерелами (коштами державного бюджету України, витратами обласних державних адміністрацій та органів місцевого самоврядування).

Вивчено досвід міжнародного фінансування збереження природного капіталу за рахунок екологічних фондів, коштів громадських організацій та 
грантових проектів. Науковий та практичний інтерес у роботі складає запропонований механізм фінансування збереження природного капіталу в сучасних економічних умовах розвитку України.

Досліджено організаційну структуру державного управління збереженням природного капіталу України. Проаналізовано ефективність державного управління збереженням біорізноманіття. Вивчено та проаналізовано функції Міністерства екології та природних ресурсів України (Мінприроди України) як центрального органу державної виконавчої влади у галузі збереження біорізноманіття. Досліджено штатний розпис Мінприроди України, проаналізовано систему розстановки кадрів та досліджено штатний розпис структурних підрозділів міністерства, що відповідальні за збереження природного капіталу України. Розглянуто кращий міжнародний досвід державного управління збереженням природного капіталу та розроблено рекомендації щодо його імплементації в Україні.

Ключові слова: природний капітал, архетипний підхід, міжнародна співпраця, управління.

\section{СУЩНОСТЬ УПРАВЛЕНИЯ ПРИРОДНЫМ КАПИТАЛОМ: АРХЕТИПНЫЙ ПОДХОД}

Аннотация. Рассмотрены вопросы сущности понятия “природный капитал”, а также управления в области сохранения природного капитала. В исследовании применен архетипный подход. Проанализированы деятельность и структура международных организаций, осуществляющих экологическую политику. Исследованы основные аспекты и особенности кооперации усилий в области сохранения природного капитала. Предложены основные мероприятия усовершенствования государственной политики сохранения и воспроизводства природного капитала.

Рассмотрены основные подходы к оценке эффективности сохранения природного капитала на основе лучшего зарубежного опыта. Осуществлена экономическая оценка природного капитала Украины и доказана необходимость увеличения объемов ежегодного госбюджетного финансирования сохранения природного капитала.

Предложена методика оценки эффективности сохранения биоразнообразия на следующих трех уровнях: общегосударственном, региональном и местном, что позволяет лучше анализировать как фактическое состояние природных экосистем, исследовать динамику расходов на содержание природного капитала по источникам (средствами государственного бюджета Украины, расходами областных государственных администраций и органов местного самоуправления).

Изучен опыт международного финансирования сохранения природного капитала за счет экологических фондов, средств общественных организаций и грантовых проектов. Научный и практический интерес в работе составляет предложенный механизм финансирования сохранения природного капитала в современных экономических условиях развития Украины. Исследована 
организационная структура государственного управления сохранением биоразнообразия Украины. Проанализирована эффективность государственного управления сохранением биоразнообразия. Изучены и проанализированы функции Министерства экологии и природных ресурсов Украины (Минприроды Украины) как центрального органа исполнительной власти в области сохранения биоразнообразия. Исследовано штатное расписание Минприроды Украины, проанализирована система расстановки кадров и исследовано штатное расписание структурных подразделений министерства, что ответственных за сохранение природного капитала Украины. Рассмотрен лучший международный опыт государственного управления сохранением природного капитала и разработаны рекомендации по его имплементации в Украине.

Ключевые слова: природный капитал, архетипный подход, международное сотрудничество, управление.

Formulation of the problem. In recent years, the preservation of Ukraine's natural wealth has become particularly relevant and has become one of the problems of our time. This question creates a real ground for ensuring the country's ecological safety, the formation of its natural resource potential, and hence the formation of economic well-being, democratic development of the state and society. However, the system of preserving natural capital can gain elements of systemicity only due to the development of democratic foundations of the management of society and the effective functioning of the state apparatus. This situation requires the maximum concentration of efforts of all branches of power and local selfgovernment in the field of preserving natural capital, developing a system for its reproduction and multiplication as a national treasure of the state.

Analysis of recent research and publications. A large number of works by Ukrainian scientists - Ye. O. Romanenko, A. Yu. Yakymchuk, O. O. Veklych, Yu. I. Stadnytskyi, I. M. Synia- kevych, S. O. Bila and many others - is devoted to the study of the reasons for the decline of natural capital, its degradation.

The purpose of the paper is using archetypal approach to provide a general idea of the concept of natural capital and its management system on the basis of the experience of developed democratic countries, to offer the author's vision of the notion and management system for the preservation of natural capital and give suggestions on how to improve the system of preservation and reproduction of natural capital as a national wealth of the state.

Presenting main material. The management system of the preservation of natural capital, taking into account the degradation of the latter, can not be considered effective in Ukraine today. On the basis of numerous developments, the author comes to the need to use an archetypal approach as the most effective in terms of the preservation of natural capital as a fundamental social system of society. It is known that in 
order to carry out the archetypal management of social systems - by own political organizations as well as by the Ukrainian society as a whole, progressive national elites can use - along with the increase of the level of existing and the formation of new political myths by changing the meanings and content of the generated information flows in the direction of strengthening love for the neighbor, reducing aggression and expansion of the circle of "us" due to the narrowing of the circle of "them" - the organizational tools, applying in the development of their own organizations modern variable structures that allow for activation and maintenance for a long time its members within the framework of the cultural archetype with corresponding organizational culture [1]. This will result in synchronous activation in their psyche of higher levels of personal archetypes and will provide them with the choice of the appropriate behavioral models, schemes and strategies within the framework of values formed in a way of minimizing the differences between the actual political myth and the dominant cultural archetype.

Accordingly, the question about understanding the nature of natural capital in the system of archetypal management arises. One of the peculiarities of the modern period of development of both highly developed economies and developing countries is the realization that the formation of capital in its various manifestations is an important source of economic growth. The nature of capital, its essence have attracted the attention of economic thought for centuries. Depending on the level of development of productive forces and in- dustrial relations researchers in different ways responded to the question of what capital is [11].

Capital (ger. kapital, lat. capitalis main) is the resources used to produce goods and services in order to generate income [2, p. 313].

Capital is money, securities, real estate, etc., as a means of making profit, generating income [4, p. 326].

Capital represents the value in the form of financial resources and goods used to obtain its additional growth profit (income of entrepreneurs) [5, p. 143].

Capital is a value that brings added value (income stream) and has a vital desire to grow [6, p. 119].

Capital is a discounted future income, that is, capitalized income [7].

Capital is a set of industrial relations in capitalist mode of production, in which means of labor, certain material wealth, money, intellectual property and various types of securities, etc. are an instrument of exploitation, appropriation of part of someone else's unpaid labor [8, p.719]. From all these definitions, we can observe the wellknown principle of science: capital, as a fundamental category, is the value (value, resources) that brings a new value (income, profit). Thus, the essence of the notion of "natural capital" should also be based on the above mentioned principle and additionally include a broader definition than that given in the scientific publications of classical economic theory.

The notion of "natural capital", as a socio-economic category, has been introduced into scientific circulation relatively recently in the 80 's of the twentieth century in the writings of 
R. Costanzo, Hugh Daley, J. Bartholomew and other authors. The doctrine of "natural capital" is formed in the framework of a new scientific discipline, which is called "green (ecological) economy". As a result, today in the world economy of the developed countries the "green economy" becomes the dominant one, which differs from the previous economic formations by the isolation in the market process of "natural capital".

According to Daley (1998), natural capital is the stock, which is the source of the flow of natural services and real natural resources. "This sustainable flow is called "natural income", and it is provided by "natural capital"...."Natural capital can also produce "environmental services". If we make the analogy of natural capital with capital in the traditional sense used to produce goods and services - these are "stocks/assets of the natural environment, giving a flow of valuable goods and services in the future" [8, p. 130].

At the United Nations Conference on Environment and Development (Rio de Janeiro, 1992), an attempt was made to define the term "natural capital", which was called "the gift of nature to humanity" and its types were formulated:

- non-renewable or exhaustible natural capital (Depletable Natural Capital DNC) - energy resources;

- cyclically-used natural capital (Recyclable Natural Capital $\mathrm{RecNC}$ ) - non-energy mineral resources;

- renewable Natural Capital RenNC - soils and other resources of the environment.
A conference in Rio de Janeiro concluded that the loss of the functions of natural systems (natural capital) can always be compensated by the increase in Human Made Capital - HMC. However, replacement of "natural capital" with industrial capital is possible only to a certain limit and there is a limited ability to replace some parts of natural capital, by others [8, p. 131].

It should be noted that in the modern theory of the green economy the main system-forming features; criteria for the division of natural phenomena into "resources" and "secondary raw materials"; character of the process of changes in "natural phenomena" (natural objects) in "economic phenomena" (economic objects); the place of the phenomenon of "natural resource" in transitional states; the role of research in this process; criteria for determining the distinction between renewable and non-renewable natural resources (natural capital) are not clearly defined. There are doubts in use of the term "resources" (as industrial and domestic stocks) for the phenomena that exist in nature. Great difficulty arises in the process of assessing the value characteristics of natural capital by the existing methods used to determine the value of production material resources, etc. However, "natural capital" is still a rather new theoretical concept, and therefore its scientific, methodological and practical formation has just begun in both new and long-developed economies.

The widespread idea in scientific society is that natural capital is a combination of goods and services provided by nature. At the same time, natural capital retains all the properties of con- 
ventional forms of capital. This term is increasingly applied to the selection of elements of the natural environment that are valuable to people and society. In essence, from the economic point of view, natural capital represents the values given by nature for the purpose of their further use in the process of production of consumer goods and services in order to increase the well-being of people and social development.

According to the authors of the publication [9], natural capital covers three main categories: natural resources reserves, incl. water and air; soil; ecosystems and ecosystem services.

Figure depicts natural capital and its relations with other forms of "capital" through the provision of ecosystem services. At the same time, it should be noted that natural capital is considered to be the most important, since it serves as the basis of all other types of capital, such as human, social, and production capitals, and therefore it is the basis for the functioning of modern economies of all countries without exception.
1) Resource or providing services. For example, wood, food, water, etc. In other words, everything that has a market assesment and value.

2) Regulatory services: water systems regulation, carbon sequestration, flood prevention, etc.

3) Socio-cultural services. These are the benefits people receive, admiring nature, performing educational, scientific, religious functions, etc.

4) Supporting services. These are the most complex natural cycles, the deep ecological processes and phenomena.

Natural capital directly forms the national wealth of all countries without exception. This is especially true for emerging economies, which account for about $30 \%$ of total capital in the share of natural capital [9]. The economic development of most countries is due to nature, and it in turn leads to excessive spending of the natural resource base faster than the planet can restore it. As a result, human activity, especially during the past 50 years, has caused significant damage to the natural en-

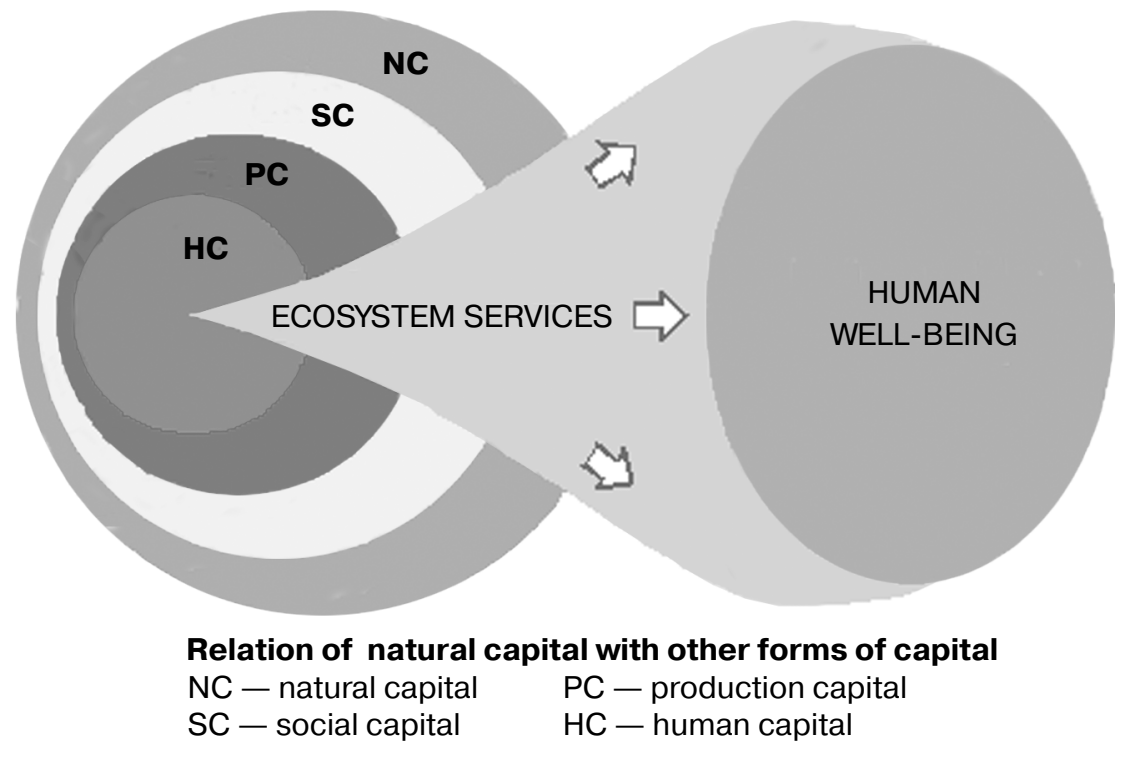


vironment. In the process of excessive use, considerable exploitation and destabilization, significant damage has been caused to the ecosystem of nature at the global level. In response to the continued increase in the use of natural capital, the global economy faces an urgent need to implement urgent measures to preserve and improve the natural potential of the planet towards sustainable development and the growth of people's well-being.

One of the main reasons for spending a significant amount of natural capital is that the cost of environmental goods and services is usually taken for granted and perceived as something infinitely affordable. Thus, natural capital is not reflected in traditional balances, income statements, in the reports on the formation of gross domestic product, both the authorities and individual economic entities. As a result, usually, too large reserves of natural resources are involved in production processes, while investments in its formation and preservation are minor and ineffective.

In this regard, the question of the strategic development of natural capital is a priority in the state policy of any country, and increasing environmental awareness in the corporate sector and society as a whole are key prerequisites for obtaining positive socio-economic results. At the macro level, the mechanisms of public administration of processes for the development of natural capital, as well as the calculation of both positive and negative consequences of the influence of human interventions in the natural environment, should be adequately reflected in the normativelegal documents. At the micro level, it is extremely important for business organizations to understand their dependence on natural resources and develop policies, tools and indicators that contribute to integrating natural capital accounting in the systems of private and corporate sector economies.

The true statement is that natural capital is an invaluable asset to Ukraine, as it plays an important role in the strategy of socio-economic development and protection of the country's natural environment. Natural capital of Ukraine includes geological elements, soils, air, water and all living organisms that provide a wide range of so-called "free" products and ecosystem services that are the basis of the national economy and society. Natural capital is considered a solid foundation for the development of the "green" economy and sustainable growth in Ukraine. The values of ecosystem services, national parks, nature reserves, natural heritage, biosphere reserves, parks of historical heritage, etc. are the basis for the functioning and development of environmentally sound sectors of the economy. The functions and values of natural capital are enormous, and therefore it is the basis for the formation of a strategy for the development of the advanced countries of the world to ensure their sustainable development. In this regard, the socio-economic development of Ukraine will also not be able to function in the long run unless natural assets of the country are preserved.

In modern conditions, the priority of economic policy of all states is economic growth [13]. In this case, the question arises: which factors provide economic growth? What are the prospects for such growth? It is known that the results and rates of economic 
growth depend directly on the attraction of natural capital components [12]. This is due to the fact that in almost all branches of material production, the main component of the product is the raw material, which is the material basis of the good that is being produced, or acts as auxiliary material, providing the production process. So, for example, the growth of China's economy is driven by the dynamic development of industry, which is accompanied by an increase in consumption of metals, including steel, copper, zinc, nickel, aluminum [14, p. 221]. The growth of national economies in post-Soviet countries such as Armenia, Azerbaijan, Tajikistan, and Turkmenistan is associated with an increase in exports of natural gas and petroleum products. It should be noted that the Ukrainian economy is also largely dependent with its economic growth on the use of national natural capital, the components of which are massively exhausted and liquidated.

During the last 100 years, the consuming of components of non-renewable natural capital such as zinc, chromium, copper, magnesium, molybdenum in world economy has increased in 28 thousand times. To meet the needs of production in raw materials for this period, 1100 million tons of iron ore, 10 million tons of copper, 5,5 million tons of zinc, 2,5 million tons of lead, 1 million tons of nickel, more than 2500 tons of gold, 120 million carats of diamonds, etc have been mined. [15, p. 24].

Consequently, strong economic growth in the twentieth century and in the second decade of the XXI century were accompanied by the involvement in the production of an increasing amount of natural capital, exhausting it. It is fair to note that, with the accession of some developed countries and those developing in the post-industrial development, their needs for materials and raw materials are constantly shrinking in favor of increasing the share of industries that produce knowledge and information products in the national product. But on the scale of the world economy the role of the natural factor remains significant [12]. The share of costs for raw materials and materials still exceeds half of world GDP, and in the world industrial production, their share reaches more than $70 \%$ [16, p. 52].

In this context, American researchers J. Tinbergen and R. Huting emphasize the existence of a direct dependece between the degree of loading of the field of economic activity on the environment and the share of its contribution to the structure of GDP. J. Tinbergen and R. Huting's research has shown that $30 \%$ of the activities increase production by about $70 \%$, and therefore they are the most conducive to economic growth [17; 18]. These are the very types of activities (oil, chemical, metallurgical, mining and woodworking industries, agriculture, road construction, transport, etc.) which, by contamination of air, the use of land, soils and other components of natural capital, cause the greatest damage to the environment, that is, there is the most burdensome for nature. At the same time, the replacement of $1 \%$ of environmentally harmful activities with the environmentally sound ones will lead to an 1,8\% decrease in national income [19, p. 129].

It should be noted that in Ukraine one of the most ecologically "dirty", 
environment-intensive economies has been formed - it is saturated with metallurgical, chemical and mining industries with outdated technologies. The industry producing raw materials, metals and energy resources, accounts for more than $2 / 3$ of the total volume of industrial products [20, p. 102; 20]. The consequence of such raw material orientation of domestic production is, firstly, the reduction of national natural capital, that makes disappointing prospects for further economic growth, and secondly, the strengthening of the dependence of the national economy as a whole on the situation on the external markets of raw materials. Achieving economic growth without taking into account environmental interests has led to the appearance and aggravation of problems of provision of production with the necessary components of natural capital in time and space. As a result, the domestic economy in the present conditions has acquired a specific feature: its growth has become limited, as a rule, "survivable" natural capital. And the economic growth achieved through the exhaustion and degradation of natural capital is distorted, unbalanced and can not be sustained for a long time. Only by investing in the formation of natural capital a rapid and balanced growth of the national economy can be achieved and the overall economic welfare of the population can be improven [12-16].

Substantial research of natural capital in the system of formation of an environmentally balanced economy has become the object of studying for foreign and Ukrainian scientists. The new approaches to the preservation of natural capital in the conditions of for- mation of ecologically balanced development of the economy were formed by such well-known scientists of the twentieth century as G. Daley, J. Cobb, R. Kostanza, S. El Serafi, J. Tinbergen, R. Huting and others.

This problem is actively explored in the post-Soviet space, including Ukrainian scientists. In view of the complexity, the multidimensionality of the problem, scientific developments of scientists can be systematized in the following groups:

- researches connected with the study of interrelationships "nature man - nature" (G. Bachynskyi, M. Holubets, C. Zlupko, B. Nekos, O. Palamarchuk, V. Popovkin, O. Shabliy);

- research related to the theoretical modeling of the ecologically balanced use of natural capital in the economy (A. Alexandrov, O. Badrak, Yu. Bazhal, V. Baranovskyi, B. Danylyshyn, E. Girusov, A. Golub, L. Grinov, L. Melnyk, B. Prykin, M. Rudenko, G. Strukova, L. Shostak);

- studies related to the management of the process of environmental improvement (O. Veklych, O. Vrublevska, I. Grabynskyi, M. Dolishnii, I. Mykhasiuk, L. Ribun, I. Syniakevych, Yu. Stadnytsky, V. Stepanov, Yu. Tunytsia, S. Harichkov, V. Shevchuk).

Conclusions. The preservation of Ukraine's natural capital, and in particular the process of its reproduction, should be built on systematic management and based on the application of an archetypal approach. Such an approach will allow to take into account the public values of natural capital, the cultural development of the individual, based on love for nature, its ecological value, as the fundamental basis of development 
of society as a whole. In addition, the achievement of economic growth of the state is impossible without taking into account environmental interests. The economic growth achieved through the exhaustion and degradation of natural capital is distorted, unbalanced and can not be sustained for a long time.

\section{REFERENCES}

1. Romanenko E. and Chaplai I. (2011), "Marketyng u derzhavnomy upravlinnii: arhetypnyi pidhid", Publichne vriaduvannia [Online], vol. 1, available at: https://cyberleninka.ru/ article/v/marketing-u-derzhavnomuupravlinni-arhetipniy-pidhid.

2. Borodulin V.I., Gorkin A. P., Gusev A.A. (2000), Novyj illyustrirovannyj enciklopedicheskij slovar' [New Illustrated Encyclopedic Dictionary], Bol'shaya Ros. Ehncikl, Moskva, Russia.

3. Rajzberg B. A., Lozovskij L. S. and Starodubceva E. B. (2003), Sovremennyj ekonomicheskij slovar' [Modern Economic Dictionary], INFRA-M, Moskva, Russia.

4. Sklyarevskaja G. N. (2001), Tolkovyj slovar' sovremennogo russkogo yazyka. [Explanatory dictionary of the modern Russian language], OOO "Izd-vo Astrel”, Moskva, Russia.

5. Borisov E. F., Petrov A .A. and Sterlikov F. F. (1998). Ekonomika: Spravochnik [Economics; directory], Finansy i statistika, Moskva, Russia.

6. Ignatov T. V. (2001), Ekonomika. Kratkij slovar' [Economics: short dictionary], Feniks, Rostov na Donu, Russia.

7. Zagorodnij A. G. and Voznyuk G. L. (2013), Slovnik ekonomichnoi aforistiki [Dictionary of economic aphorism], Vidavnictvo L'vivs'koï politekhniki, L'viv, Ukraine.

8. Puhova U. M. (2008), "Natural capital", as part of the constituent natural resources", Fundamental'nye issledovaniya, vol. 1, p. 130-132.

9. Burkins'kij B. V., Galushkina T. P. and Reutov V. E. (2011), "Zelena ekonomika" kriz' prizmu transformacijnih zrushen' v Ukraïni”, PP "Feniks", Odesa, Ukraine.

10. "Europe 2020" is the strategy of the social and economic development of the European Union for the period until 2020 (2010), "News of the region", available at: http://eeas.europa. eu/delegations/ukraine/documents/ eurobulletin/eurobulet_04_2010_ uk.pdf (Accessed 4 April 2018).

11. Cabinet of Ministers of Ukraine (2007), "The Concept of National and Ecological Policies of Ukraine for the period up to 2020", available at: http://zakon.rada.gov.ua/cgibin/ laws/main (Accessed 4 April 2018).

12. Towards a "green economy". Ways to sustainable development and poverty eradication (2011). available at: http://www.unep.org/greenecono$\mathrm{my} /$ portals/88 documents/ger/ger synthesis_r u.pdf (Accessed 4 April 2018).

13. Ministry of Economy of Ukraine (2010), "National report "Millennium Development Goals. Ukraine" [Research and innovation activity in Ukraine 2008. Statistical yearbook], Derzhkomstat, Kyiv, Ukraine.

14. Pidlisnyuk V.V.,Zagimyak M. V.and Irkova I. (2013), Strategiya stalogo rozvitku ta zmin klimatu [Sustainable Development and Climate Change Strategy], Vidavnictvo "SHCHerbatih", Kremenchuk, Ukraine.

15. The Green Economy (2011), [The UNEP Magazin for Youth], TUNZA, UNEP.

16. Hlobystov E. V. (2004), Ekologichna bezpeka transformacijnoï ekonomiki [Ecological security of the transformational economy], Agentstvo "Chornobil'interinform”, Kyiv, Ukraine. 


\section{СПИСОК ВИКОРИСТАНИХ ДЖЕРЕЛ}

1. Романенко С. О., Чаплай I. В. Маркетинг у державному управлінні: архетипний підхід [Електронний ресурс]. - Режим доступу: // https:// cyberleninka.ru/article/v/marketingu - d e r z hav n o m u - u p rav linn i arhetipniy-pidhid

2. Новый иллюстрированный энциклопедический словарь / ред. кол.: В. И. Бородулин, А. П. Горкин, А. А. Гусев и др. - М.: Большая Рос. энцикл., 2000. - 912 с.

3. Современный экономический словарь / сост. Б. А. Райзберг, Л. Ш. Лозовский, Е. Б. Стародубцева. - 4-е изд., перераб. и доп. - М.: ИНФРАM, 2003. - 479 c.

4. Толковый словарь современного русского языка. Языковые изменения конца ХХ столетия / ИЛИ РАН; под ред. Г. Н. Скляревской. - М.: ООО “Изд-во Астрель", 2001. - 944 с.

5. Борисов Е. Ф., Петров А. А., Стерликов Ф. Ф. Экономика: справочник. 2-е изд. - М.: Финансы и статистика, 1998. - 400 с.

6. Экономика. Краткий словарь / под ред. Т. В. Игнатова. - Ростов н/Д.: Феникс, 2001. - 336 с.

7. Словник економічної афористики / уклад.: А. Г. Загородній, Г. Л. Вознюк. - Львів: Вид-во Львів. політехніки, 2013. - С. 181.

8. Пухова У. М. “Природный капитал”, как часть составляющего природных ресурсов // Фундаментальные исследования. - 2008. - № 2. С. 130-132.

9. Буркинсъкий Б. В. "Зелена економіка” крізь призму трансформаційних зрушень в Україні / Б. В. Буркинський, Т. П. Галушкіна, В. С. Реу- тов. - Одеса: ІПРЕЕД НАН України - Саки: ПП “Фєнікс”, 2011. $348 \mathrm{c}$.

10. “Европа 2020” - стратегия социально-экономического развития Европейского Союза на период до 2020 года, 2010 [Электронный ресурс]. Режим доступа: http://eeas.europa. eu/delegations/ukraine/documents/ eurobulletin/eurobulet_04_2010_ uk.pdf

11. Концепція національної екологічної політики України на період до 2020 року, схвалена розпорядженням Кабінету Міністрів України від 17 жовтня 2007 р. № 880-р [Електронний ресурс]. - Режим доступу www.zakon.rada.gov.ua/cgibin/laws/ main

12. Навстречу “зеленой экономике”. Пути к устойчивому развитию и искоренению бедности. Доклад ЮНЕП, 2011 [Электронный ресурс]. - Режим доступа: http://www. unep.org/greeneconomy/portals/88/ documents/ger/ger_synthesis_r u.pdf

13. Начіональна доповідь “Цілі розвитку тисячоліття. Україна” // Мін-во економіки України. - К.: Мінеконом. України 2010 р. - С. 91, 95, 9697.

14. Підліснюк В. В., Загірняк М. В., Їркова I. I. Стратегія сталого розвитку та змін клімату / за ред. В. В. Підліснюк. - Кременчук: Щербатих, 2013. - 224 c.

15. The Green Economy// TUNZA (The UNEP Magazin for Youth), 2011. - 9, № 4. $-24 \mathrm{p}$.

16. Хлобистов 6 . В. Екологічна безпека трансформаційної економіки / РВПС України НАН України / відп. ред. С. І. Дорогунцов. - К.: Агентство “Чорнобильінтерінформ”, 2004. $336 \mathrm{c}$. 